\title{
Human Rights inside the United Nations: The Humphrey Diaries, 1948-1959.
}

\author{
by A. J. Hobbins
}

This article is based on the diaries of John Humphrey, first Director of the Human Rights Division of the United Nations from 1946-1966. It is a continuation of an earlier work based on the Humphrey Papers dealing with the drafting process of the Universal Declaration of Human Rights in 1947. Humphrey began keeping a diary in August, 1948, and the first fourteen covering from then until 1959 are in the author's possession. While it is hoped these diaries will one day be published in full, this article concentrates on the adoption of the Universal Declaration, Humplorey's friendship witb Gabrielle Roy, the difficulites associated with the investigations of U.N. personnel by the Federal Grand Jury and the Senate Subcommittee on Internal Security in 1952, and the conflict between the diplomatic role of the Secretary-General and the work of the Human Rights Division under Hammarskjöld.

Cet article repose sur les journaux intimes de Jobn Humphrey, premier directeur de la Division des droits de l'bomme des Nations unies de 1946 à 1966. Il fait suite aux recherches déjà effectuées dans le cadre du fonds Humpbrey sur la rédaction de la Déclaration universelle des droits de l'bomme de 1947. Humphrey a commencé à tenir son journal en aot 1948 et les quatorze volumes allant de cette période jusqu'à 1959 sont en sa passession. Même di l'on espère que ces journaux seront un jour publiés dans leur intégralité, cet article est uniquement centré sur l doption de la Déclaration universelle, sur l'amitie d'Humphrey è de Garielle Roy, sur les difficultés nées des enquêtes menées en 1952 par le Federal Grand Jury et le Subcommittee on Internal Security du Sénat sur les membres des Nations unies ainsi que sur les conflits entre le rôle diplomatique du Secrétaire général et la division des droits de l'bomme dirigée alors par Hammarskjöld.

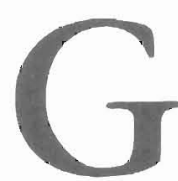

eneva, Aug. 3, 1948

Dinner at flat of Ste-

phane and Vitia Hessel. Mendes-France and Laugier in argument re "troisième colosse". Laugier says that peoples of the world, including those of Russia and U.S.A., must be organized and united against the two governments that are responsible for present tension. The peoples of the world and the governments of the smaller countr[ies] do not want war. This a familiar theme in talks with Laugier who is looking for a spokesman for the "troisième colosse". But Mendes-France found the formula an over-simplification. No government, he says, not even the American nor the Russian, wants war. In any event, France could not lead the "troisième colosse". "Pour la France il y a maintenant pas d'action internationale: il y a seulement une action interne".

Thus, almost "in medias res" as befits a work of epic proportion, ${ }^{1}$ John Humphrey began the diary that he was to keep with relative faithfulness for at least eleven years, and of which an overview is given in this article. Humphrey, a graduate from four faculties of McGill University, had taught law at that institution from 1936 until he was named Dean of Law in 1946. As he was about to leave on a last vacation before taking up that office, he received a telephone call from an old friend, Henri Laugier. ${ }^{2}$ Laugier, a 
Frenchman, had spent part of the war in exile in Montreal, but was by then the Assistant Secretary-General in charge of Social Affairs for the fledgling United Nations. He asked Humphrey to become the first Director of the Human Rights Division in the U.N. Secretariat. When Humphrey accepted he interrupted a quiet academic life-- which still continues-with a twenty year hiatus in the dizzying world of international affairs. One of his first tasks, after setting up the Division, was to aid in the process of getting the General Assembly to adopt an International Bill of Human Rights. Daily he found himself in contact with figures of world renown such as Eleanor Roosevelt, first Chairman of the U.N. Commission on Human Rights, and the French lawyer, René Cassin, later a Nobel Laureate for his work in the field. As Secretary of the Commission's Drafting Committee, Humphrey himself prepared the first draft of the Declaration. ${ }^{3}$ The work of refining and redrafting the document took the Commission a further eighteen months of arduous meetings on two continents. Much of the important work was done outside the formal meetings in the corridors or at the numerous cocktail parties and dinner engagements.

One such engagement took place in Geneva in August, 1948. Stephane Hessel, Laugier's Executive Assistant, held a dinner party at which a conversation between Laugier and Pierre Mendes-France, then the French Representative on the Economic and Social Council and later a socialist Prime Minister of his country, fascinated Humphrey. Here were two influential men arguing about whether France could lead a number of countries to form a third super-power to offset the influence of the United States and the Soviet Union, whose relationship it was feared would lead to another war. On returning home, Humphrey wrote his first entry in a plain spiral-bound stenographer's pad.

\section{THE DIARIES}

There are currently fourteen diaries, all on stenographer's pads, in the present author's possession covering the period August 3rd, 1948, to February 3rd, 1959. It is possible that more diaries exist, for Humphrey did not retire from the U.N. until 1966, but these have not yet been found. The diaries follow the same pattern. Each spiral bound pad has the inclusive dates, residence addresses and sequence number on the front cover. Humphrey wrote the entries, some of which go on for several pages, late at night while his wife, Jeanne, was preparing to go to bed. The entries cover the day's business activities, luncheon and dinner engagements, as well as personal, cultural and social activities, with Humphrey's commentaries on any of the above. Humphrey is an astute observer of things, both animate and inanimate, and he is a man of strong opinions. His role as international civil servant prevented him from expressing these opinions in public on most occasions. One exception is found in the entry for Tuesday, December $7 \mathrm{th}, 1948$.

Yesterday again the Committee sat until the middle of the night and I did not get to bed until 3.30 a.m. But we finally adopted the Universal Declaration of Human Rights-as it will now be called. ${ }^{4}$ There were no votes against but seven abstentions: the six Eastern European States and Canada. The Canadian vote came as a great surprise but I learned today that it will be changed when the declaration comes before the plenary. ${ }^{5} \mathrm{I}$ am afraid that $I$ exceeded my prerogatives as an international servant when afterwards I expressed my indignation to the Canadian representative. This has apparently caused some talk, because today I had the visit of a representative of the Canadian Press, sent to me strangely enough by the Canadian Delegation, who wanted me to say for publication in Canadian newspapers that I had been shocked by the Canadian vote. I had to give him a lecture on the status of an international official!

Restricted from public utterances, Humphrey used his diaries to express his candid feelings on all manner of issues. At the end of the first week of writing, he attempted to analyze his reason for starting the project: 
Sunday, Aug. 8 [1948, Geneva $]^{6}$ ...

I should discipline myself to write essential things only in this diary.

Finished the volume 1939-1942 of Gide's Journal. ${ }^{7}$ It is merely a coincidence that I should have begun writing this diary while reading Gide. I have thought about keeping a diary ever since I entered the Secretariat on I August 1946. One of the things, apart from lack of time, that has kept me from it is my distrust of myself in writing. One neglects or is unable to put down the really important things; and how great a difference there is between what we really think and the interpretation of our thoughts that gets on paper! Laziness is partly responsible for this-but only partly.

He sometimes found the task difficult after busy days and late nights, both often filled with frustrations, as witnessed by the two following excerpts:

\section{Aug. 13. [1948, Geneva] \\ There is a great similarity between the actions of nations and those of children. I could develop this thought at length were it not for the temptation of reading. Moreover, I am tired. \\ Aug. 21. [1948, Geneva] \\ It is I who am tired tonight. It is from fatigue that this diary suffers more than anything else. Many interesting things happen during the day, but when night comes I am too tired to write about them, and certainly too tired to think.}

He quickly found that it was difficult to catch up if he did not force himself to make daily entries. The frailty of human memory also surprised him, when he wholly forgot things that should be familiar.

Basle, Aug. 29 [1948]

One of the unconvincing things about Simone de Beauvoir's immor- tal Fosca is his prodigious memory. ${ }^{8}$ His mind retains everything from early days in Carmona up through the centuries. Had the author provided him with a human memory he would have born his immortality more lightly. My experiences of yesterday and today show some of the limitations of human memory.

So Humphrey persevered and produced a remarkable series of manuscripts which are of great value to the study of the United Nations' organization in general and its human rights activity in particular. This article will, of necessity, concentrate only on a few topics covered by the diaries: these include the adoption of the Universal Declaration of Human Rights, the response of the United Nations when the rights of its own employees were violated by the U.S. investigation into subversive activities, and the conflict under the Hammarskjöld regime between the codification of human rights and the diplomacy exercised by the Secretary-General.

\section{PORTRAIT OF THE AUTHOR}

Before embarking on any analysis of unfolding international events as witnessed by Humphrey, it is necessary to examine some of his background, inclinations and biases to place his perceptions in context. Humphrey is from New Brunswick and of Protestant stock. His first wife", who was by his side during the whole period of his public life, was a FrenchCanadian Catholic and it was she who taught him the French which was to prove so useful later in life. They met on a ship when Humphrey made a trip to Europe on a McGill scholarship in 1929. They were married shortly afterwards ${ }^{10}$ in Paris in a civil ceremony conducted by the British ConsulGeneral. Humphrey did not convert to Catholicism and the Church would not recognize the marriage, despite the couple's best efforts. When they left the church after an interview with a priest, Humphrey's sister, Ruth, took a photograph. This was sent to his parents-in-law, as yet unmet, with the notation "Jeanne and John coming out of the church", leaving his new relations to draw what conclusions they might. Humphrey is a 
straight-forward man, but he is also a lawyer not above attempting to keep the social peace. His lack of a strong faith bothered but had not, to this point, changed him:

Sept. 8 [1948, Lauriot near Moëlau in Brittany]

...I was impressed by the sermon which was delivered by the rector of the seminary in Quimper. The theological structure (necessity of approaching God through the Virgin, etc. etc.) was artificial and could hardly be accepted by anyone of average intelligence, but the, to me, more profound theme was unattackable. There is something, which we have learned to call the Christian ethic (these are my own not the priest's words), without which life is mean and egotistical. It is mainly because, putting all his faith in the achievements of Science, man has forgotten this ethic that the world has gotten itself into its present mess. I profoundly believe that this is true. Surely a world that can achieve the atomic bomb but fail in the creation of the United Nations is morally bankrupt. And this moral bankruptcy is the reason for our failure to organize peace. I once thought that socialism could fill this moral gap; but now, although I still remain a socialist, I know better. For Socialism is a technique and nothing more. What we need is something like the Christian morality without the tommyrot.

Sept. 27 [1948, Paris]

There was a special mass at Notre Dame yesterday for the United Nations. We arrived very late, after Cardinal Suhard's" sermon; but we saw the procession which ended the ceremony and were given an opportunity to kiss the cardinal's ring. I shook his hand instead. Jeanne says that this was a gross breach of etiquette; but for me it was a matter of principle.
Politically, as noted above, Humphrey considered himself a socialist. This was not surprising for a life-long friend and colleague of Frank Scott, 12 one of the founders of the Cooperative Commonwealth Federation, Canada's first socialist party. Humphrey, Scott, King Gordon ${ }^{13}$, David Lewis ${ }^{14}$, Frank Underhill ${ }^{15}$ and Eugene Forsey ${ }^{16}$ had all been members of the League for Social Reconstruction, the intellectual precursor of the C.C.F. Humphrey's views by today's standards are tame and would be described as liberal. Yet in those days of McCarthy he was considered radical indeed. His inclusion of social and economic rights in the first draft of the declaration was thought of as communistic by many Americans, who wished-if they wished anything - a concentration on civil and political rights. He notes:

$$
\text { Paris, Sept. 21. [1948] }
$$

...

My attention has been drawn to a speech by the President of the American Bar Association, Frank E. Holman ${ }^{17}$, as reported in the N.Y. Times of Sept. 18. He says that the U.N. human rights programme is an attempt to establish State socialism "if not communism". Dolivet ${ }^{18}$ tells me that in another N.Y. paper he is reported as having mentioned me personally as having admitted the "revolutionary" character of the programme. Of course it will be revolutionary if we succeed; but there is nothing particularly revolutionary in what we have done up until now.

In July, 1947, Humphrey had addressed the American Academy of Political and Social Science at Ann Arbor. He felt the terminology he used-that what the United Nations was trying to do in the field of human rights was "revolutionary in character"-would be appropriate when addressing a gathering of scholars. ${ }^{19}$ This remark dogged him for all his public career, being a watchword for the right-wing opponents of the human rights programme. Even as late as 1962, Barry Goldwater was misquoting him and, with typical inaccuracy, assigning him the unusual and 


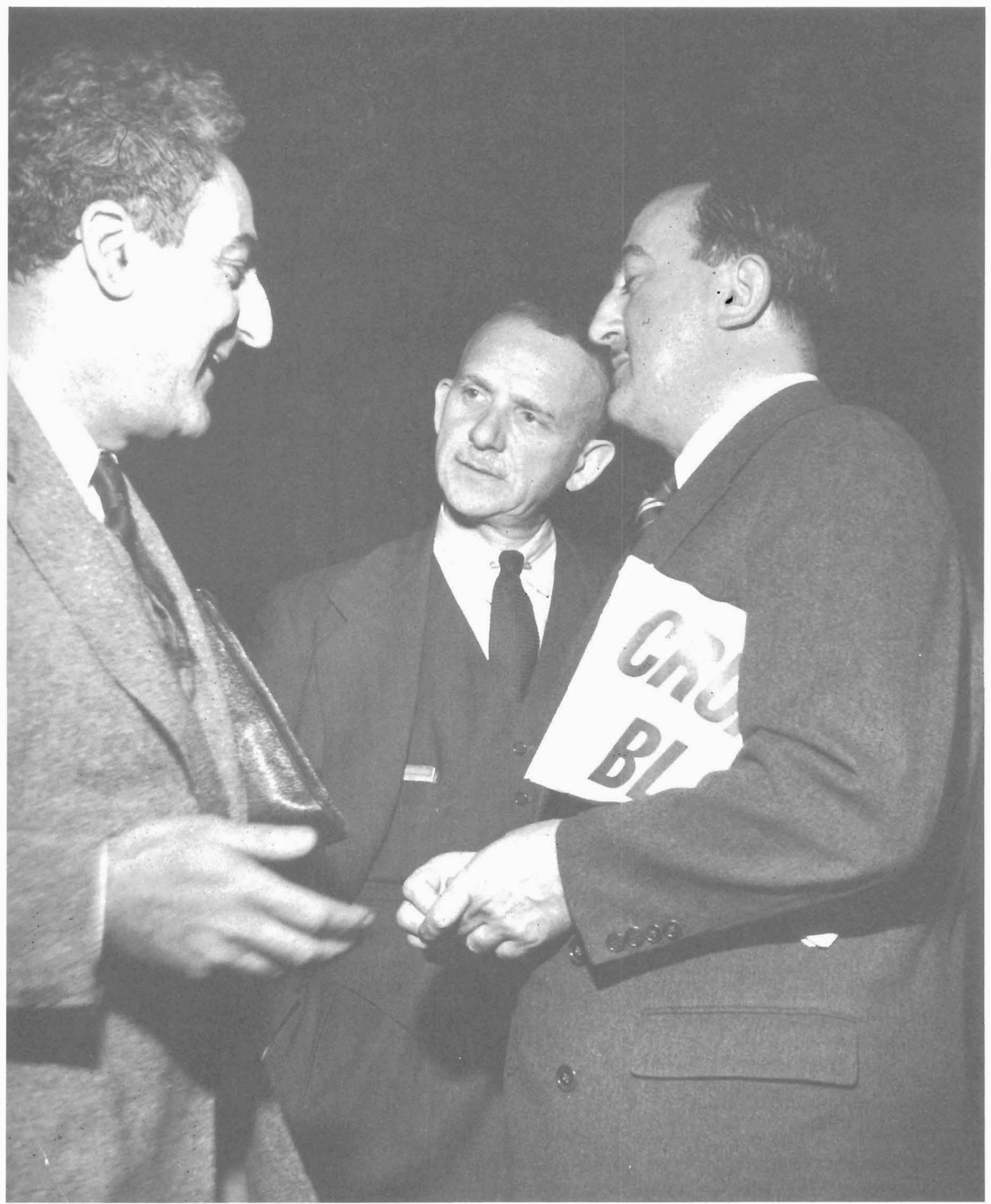

Hernan Santa Cruz (right) and Humphrey (centre) appear unconvinced by Chairman Charles Malik's explanation after a meeting of the Commission on Human Rights in New York, 1952. 
non-existent title of director of the Commission on Human Rights. ${ }^{20}$

Humphrey is well read and the diaries keep us abreast of his reading matter and his opinions which, to be fair, he is capable of revising. For instance:

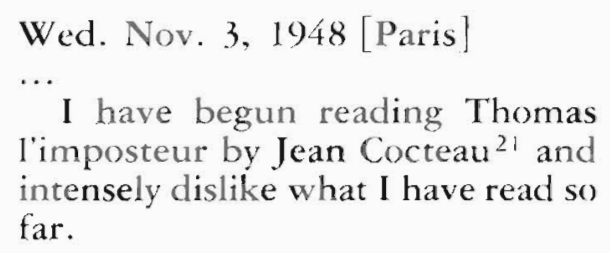
which I had abandoned since Concarneau. How refreshing after Cocteau, who however I found somewhat better after the first pages.

$$
\begin{aligned}
& \text { Monday, Nov. } 8 \text { [1948, Paris] } \\
& \text {... Finished Thomas l'Imposteur-a } \\
& \text { better book than I thought it would } \\
& \text { be after the first few pages. But } \\
& \text { Cocteau is hardly a great writer. }
\end{aligned}
$$

The diaries abound with visits to the opera, the ballet, concerts and art galleries, as well as country walks where dozens of types of flora and fauna are enumerated. One example-his view of a Picasso exhibit-is typical:

$$
\text { Oct. } 9[1948 \text {, Paris }]
$$

We visited for a few minutes this afternoon an exhibition of Picasso paintings and drawings. I belicve Picasso to be a great painter; but my honest reaction this afternoon was that he had done the things which we saw to pass the time and amuse himself-like a man who 'doodles' while listening to a speech-and perhaps even as a kind of joke on his indiscriminating admirers. If anyone else but Picasso had done these things one would not have given them a second look.
The large part of the diaries, however, deals with Humphrey's day-to-day work as Director of the Human Rights Division.

\section{THE ECONOMIC AND SOCLAL COUNCIL}

By August, 1948, the Human Rights Commission had forwarded its draft declaration to the Economic and Social Council (ECOSOC), which met in Geneva. Once considered by the Council it would be sent in turn to the General Assembly, which was to meet later that year in Paris. Charles Malik ${ }^{22}$, President of ECOSOC, also chaired the special human rights committee established to deal with the declaration. Humphrey began to find this phase of the process very frustrating.

\section{Aug 5, 1948 [Geneva]}

The special committee which the Council set up to study items on its agenda relating to human rights is now in its third week and is still considering the Report of the second session of the Commission on the Status of Women to which same report the Council also devoted many days at its sixth session. This means that there will remain very few days for study of other items: freedom of information, genocide and the draft Declaration of Human Rights. It would be unfair to blame the women for this. The Russians have used the occasion to attack the western powers, and particularly the U.S.A. Some of Pavlov's ${ }^{23}$ interventions have lasted for an hour or more. But it is the president of the Council who is chiefly responsible for the situation. He invites debate, does little to direct the discussion, and tries to be everybody's friend. As a consequence the delegates ride off furiously in every direction. ${ }^{24}$ Nor will Malik allow anyone else to preside over this particular committee.

\section{August 6 [1948, Geneva]}

After much procedural debate, the Human Rights Committee 
decided yesterday that it would finish its debate on the status of women today, even if it had to sit through the night. Thanks mainly to the expectation of caviar and vodka at the Russian cocktail party this evening, we did manage to finish with most of the report at 6 p.m.

These last three weeks have been among the worst that $I$ have spent at the U.N. Nothing could have been more artificial than this debate on the status of women, nor have I often witnessed more intellectual dishonesty. But Madame LeFaucheux ${ }^{25}$, the chairman of the commission, is very pleased with the result.

Malik threatened to call off this afternoon's meeting unless we could find him a stop watch. I would have liked to call his bluff.

ECOSOC, through its special human rights committee, was perhaps attempting to do too much. In addition to the draft International Declaration of Human Rights, the committee had to deal with the report of the Commission on the Status of Women, the draft convention on genocide and three draft conventions on freedom of information. ${ }^{26}$ Most of the debates concerned procedural rather than substantive matters, possibly with some intention of preventing the Declaration going to the General Assembly. Humphrey continued:

\section{Aug. 9 [1948, Geneva]}

The Human Rights Committee adopted today one paragraph of article one of the first of the three draft conventions before it. ..., I calculate that we will get the Declaration on H.R. and the Genocide Convention by about Christmas; but, alas, the Council will be in session for only a couple of weeks more.

\section{Aug. 10. [1948, Geneva]}

The situation in the h.r. committee becomes more and more serious. We have discussed freedom of information for three days, but so far haven't adopted one article of the first of the three draft conventions. There has been a good deal of talk of sabotage, etc. I myself feel that it simply shows that the Ecosoc is not organized to do this kind of detailed drafting.

...

\section{Aug. 17 [1948, Geneva] ..}

The situation in the h.r. committee is due mainly to three things: 1 ) the failure of the president ${ }^{27}$ to give lead [?] leadership or indeed even to preside, 2) simple lack of courage on the part of delegates when dealing with the Report of the Commission on the Status of Women, and 3) Pavlov, who has talked ten times at least as much as any other delegate. One of the interpreters is even reported to have described a conversation between Pavlov and other members of the Soviet delegation who were criticizing him because of his longwindedness and school-masterly manners. He seemed upset this afternoon and quite lost his temper once when Kotsnig ${ }^{28}$ [i.e. Kotschnig] tried to inter[r]upt him on a point of order. This time at least he was not acting.

As time passed and pressure to complete business mounted, the Council began to consider either staying in session indefinitely or limiting its agenda to the Draft Declaration and postponing discussion on the conventions on genocide and freedom of information. Lightheadedness crept in.

Aug. 19. [1948, Geneva] George Davidson ${ }^{29}$ handed me the following during this morning's meeting of the h.r. commirtee:

Genocide Genocide

Ziss Boom Bah

Serve it up, serve it up

Raw, Raw, Raw 
Droits de l'Homme, Droits de l'Homme

Servis plein de sang

Par le chef de délégation

P.C. Chang, ${ }^{30}$

A little information

Can do a lot of harm

So turn the whole thing over

To the cominform.

During the same meeting both Paviov and Katz-Suchy ${ }^{3}$ seriously argued that a convention ratified by two states only could not impose legal obligations. This can only be compared to the argument maintained by the same two yesterday that the sovereign and absolute right of States to refuse entry of foreigners into their territory cannot be interfered with by international treaty.

...

The Council did not complete its business, ultimately deciding to forward the Declaration and the conventions to the Third Committee of the General Assembly ${ }^{32}$ which was meeting later that year in Paris. Indeed ECOSOC did not change a word or comma in the texts of the Declaration and the Convention on Genocide that it had received. Humphrey left Geneva on August 28th, while the Council was still in session, to attend a conference ${ }^{33}$ in Brussels and to take a three-week vacation before the General Assembly meeting.

\section{A LITERARY INTERLUDE}

During their vacation, the Humphreys arrived in the picturesque town of Concarneau, in Brittany. There Humphrey noticed, little escaping his eye, an unusual sight for that part of the world-a car bearing a licence plate from the Province of Manitoba in his native Canada.

Sept. 11, 1948 [Concarneau] Shortly after our arrival in Concarneau ${ }^{31}$ we noticed a car at the back of the hotel ${ }^{35}$ with a Manitoba licence. I discovered that this belonged to a Dr. \& Mrs.
Marcel Carbotte with whom we soon developed a speaking acquaintanceship. Last night we talked to them about Montreal and Canada in general. After retiring to our room I suddenly realized that Mrs. Carbotte must be Gabrielle Roy and so she turned out to be.

This afternoon we went for a long drive with the Carbottes, leaving the hotel at one and not returning until nine...

Gabrielle Roy seemed ill and unhappy. One felt that she would like to get back to Canada away from all these distractions.

Gabrielle Roy was a Franco-Manitoban, some four years younger than Humphrey. She had lived in France before 1939, and spent the war years in Montreal as a freelance writer. At the time she met the Humphreys, only her first novel-the award-winning Bonbeur d'occasion (1945)-had been published. In August, 1947, she had married Marcel Carbotte, a Manitoba physician, and the next month they moved to Paris where the doctor was taking advanced medical studies at l'hôpital Broca. ${ }^{36}$ It seems inevitable that the two couples, of a similar age and with much in common, should have spent time together.

Sept. 12 [1948, Concarneau] .

Talked with the Carbottes in the evening. I introduced Mde. to the "Paroles" of Prevert ${ }^{37}$ several of which she read aloud and very well. We talked about books and writers. I was impressed by her judgment and the profundity of her understanding - and also by a certain intellectualism that one would never suspect by a reading of "Bonheur d'Occasion".

Evidently Bonbeur d'occasion, a story of grinding poverty in Montreal during the depression and the war, convinced Humphrey that Roy was likely to be more emotional and less intellectual than he found to be the case. The two couples separated having exchanged Paris addresses. At that time the Carbottes lived in the Hotel Lutetia on boulevard 
Raspail, although in October they moved to a pension in Saint-Germain-en-Laye, some fifteen miles from Paris, where they remained until they left for Canada in 1950.38 Humphrey renewed the acquaintanceship a week after his return to Paris.

Sept. 27 [1948, Paris. Date corrected in pencil to "le 26 " probably by Jeanne Humphrey]

We lunched in a little restaurant in the Place St. André des Arts, and then picked up Gabrielle Carbotte at her hotel. Spent the afternoon and dined with her-or she dined with us. In the afternoon we met Peter Alyen ${ }^{39}$ [i.e. Aylen] and his wife on the quais and the five of us returned to the same little restaurant for tea and ices. Had a passionate discussion with G.C. about the existence of God. While no longer a catholic she believes in the existence of God and even in some form of survival after death. My mind is completely open on the question of God's existence: I neither believe or disbelieve. But I am pretty sure that after death there is nothing. I used to think that proof might be found for these things; but I now realize that no man has ever discovered God by his intelligence. God, it seems, can only be discovered by an act of faith; and while I feel myself capable of such an act and know that I would be a happier man afterwards, I still cling to my intellect as my surest if imperfect guide.

...

Sept. 29. [1948, Paris]

...

On the suggestion of Gabrielle Carbotte I am reading, L'bomme tt sa destinée by Lecompté [i.e. Lecomté] du Noüy.

Pierre Lecomté du Noüy was a lawyer cum scientist turned philosopher. Before the war he had been Director of Biophysics at the Pasteur Institute in Paris and moved to the
United States during the war. His teleological studies led to the theory of telefinalism, as a goal of evolution. L'bomme et sa destinée further developed his theories, attempting to substantiate the faith in the high destiny of man by giving it a scientific basis. This reading was a shrewd suggestion by Roy, given the tenor of her discussions with Humphrey, who was clearly a man who wanted faith if there could be an intellectual or scientific justification. Humphrey also invited Roy to take an interest in his work.

Oct 1. [1948, Paris]

Jeanne and Gabrielle Carbotte spent the afternoon in the First Committee ${ }^{f 1}$ and we all dined together at the Palais ${ }^{41}$. Gabrielle seemed very excited about her experience.

Humphrey became quite fascinated by Lecomté du Noüy as the following entries indicate.

Oct $7 .[1948$, Paris $]$

...

Passages to remember from Lecompté du Noüy:

"Le Bien, c'est ce qui contribue au progrès de l'évolution ascendante et ce qui nous détache de l'animal pour nous entrainer vers la liberté.

Le Mal, c'est ce qui s'oppose à l'évolution et lui échappe par une régression vers la servitude ancestrale, vers la bête." p. 115

Oct. 9.

... This morning while listening to Chang I couldn't help thinking of the book that I am reading by Lecomté du Noüy. I leaned over to Laugier and inquired:

"Avez-vous lu Leconté du

Noüy, La Destineé de l'Homme?" -Non. Et je suis resolu à ne pas le lireAnd then after an interval, Laugier said:

"J'ai empeché L-d.-N d'être nommé professeur à l'Université de Montréal." 12 


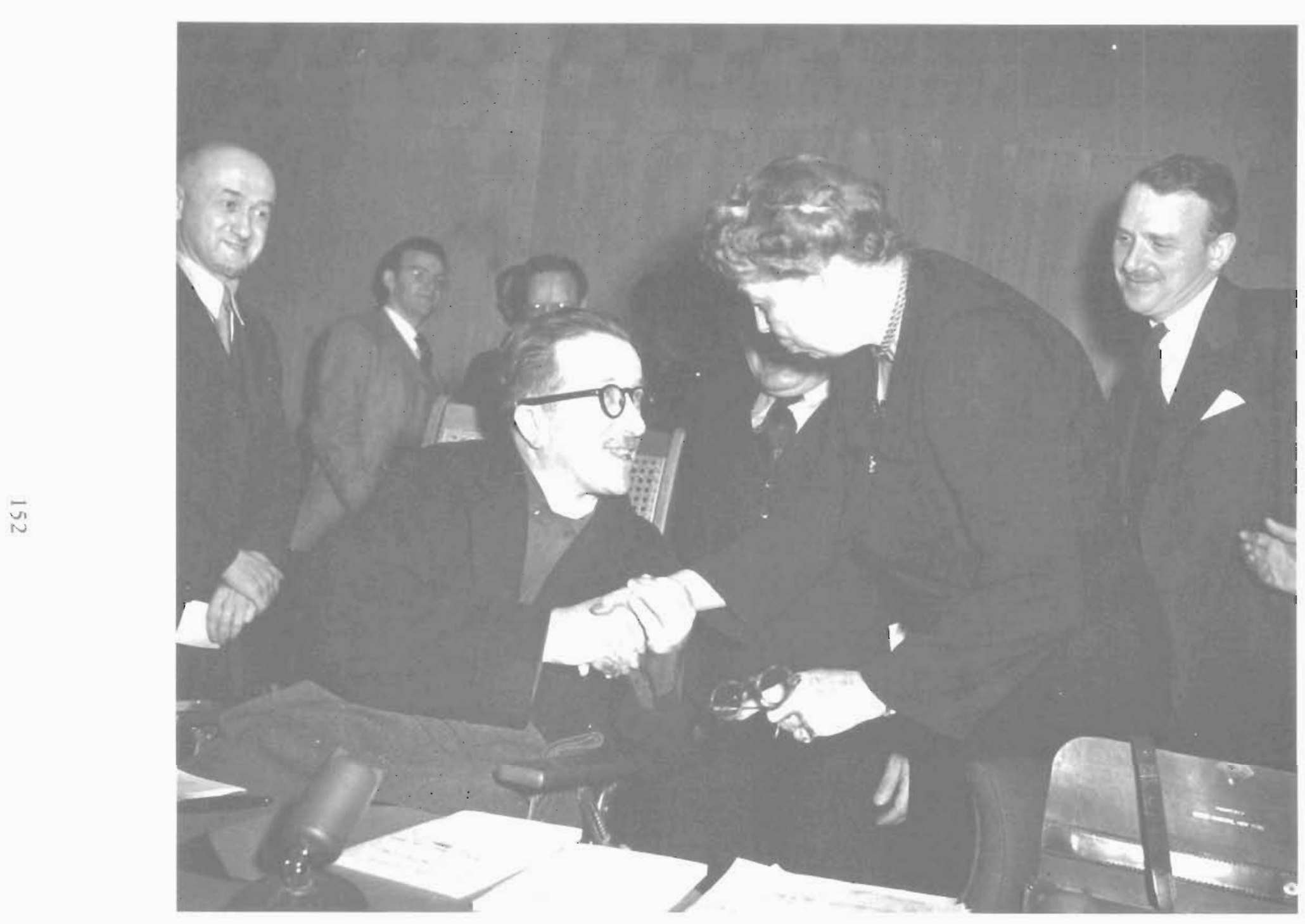

Eleanor Roosevelt welcomes Assistant Secretary-General Henri Laugier, still in a wheelchair, back to the Commission on Human Rights after his car accident. Laugier's assistant, Louis Gros (left), and Humphrey (right) look on. 
I must ask Laugier the reason for this animosity. Surely it cannot be simply Laugier's agnosticism.

Saturday, Oct 16 [1948, Paris]

I have finished L'bomme et sa destinée by Lecomté du Noüy. That man has a great destiny, provided he does not destroy himself, I have no doubt. ${ }^{13}$ I am even prepared to believe that this destiny is the purpose towards which Evolution is aiming and always has aimed. I also believe that every individual can make some contribution to the development of the race, and that he lives on as it were in that contribution. But what about the destiny of the individual, this "me"? It is litthe consolation for me to know (or to hope) that mankind has a great destiny, when I know that in a few years I shall have ceased to exist. As Gide says, what is interesting is man not mankind. And I am one of these men.

Fri. Oct. 22 [1984, Paris]

Laugier says that he dislikes Lecomté du Noüy because 1) he was an indifferent scientist, 2) because he was a poor philosopher, and 3) because he supported the Vichy regime. I wonder.

One also wonders. Laugier was agnostic and fundamentally anti-clerical; it was doubrful he would see any need to substantiate faith through a scientific basis. Lecomté du Noüy's theories were also of such a nature as to defy scientific proof, whatever their inductive rationale. One might discount Laugier's view as a difference of philosophical opinion. The ascertainable facts are that Laugier left France in 1940 with the Free French returning after the war, while Lecomté du Noüy left in 1943 and never returned. Both men were in Montreal in May, 1943, when Lecomté du Noüy gave a series of nine lectures. In a posthumous biography, '14 Lecomté du Noüy's wife states that they aicled the resistance and left France as refugees. She states that the follow- ers of de Gaulle in the new world disliked him because he was anticommunist, although this seems implausible. She is silent as to why he never returned to France. If Humphrey resolved the question he did not confide the answer to his diary even when he re-read Lecomté du Noüy the next year. Gabrielle Roy herself merited one more, almost desultory, entry.

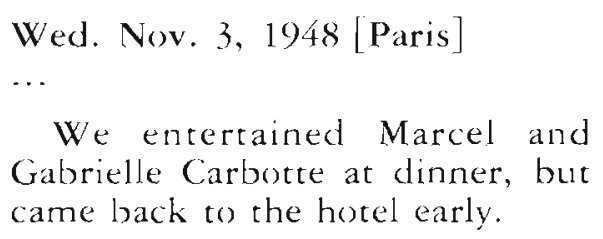

Though they parted amicably and years later were to live in the same Province, Humphrey never saw Roy again. He became very busy with the work surrounding the Declaration and left Paris on December 12 th, 1948, immediately after its adoption by the General Assembly.

\section{THE UNIVERSAL DECLARATION}

When the General Assembly met in Paris, the Third Committee concerned itself with the draft Declaration and other human rights documents. The officers were little to Humphrey's liking.

Sept. 28 [1948, Paris]

The Third Committee of the Assembly elected Mrs. Begtrup ${ }^{\text {is }}$ as its vice-president and Senator SaintLot ${ }^{16}$ of Haiti as its rapporteur this afternoon in an emotional outburst that completely disregarded compe tence and qualifications, the runners up being Thorne ${ }^{17}$ [i.e. Thorn] of N.Z. and Dehousse ${ }^{48}$ respectively. I, of course, have had some considerable experience of Mrs. Begtrup's capacities when she was Chairman of the Commission on the Status of Women. One can only hope that Malik's health remains good! (4)

In the evening we went to hear Mrs. Roosevelt at the Sorbonne. The great amphitheatre was packed with an enthusiastic audience which gave her a reception the likes 
of which I have never seen before. Ramandier, ${ }^{50}$ Cassin, and the Recteur of the University ${ }^{51}$ spoke in glowing terms. But Mrs R. in spite of her appealing opening failed to seize the opportunity that had been provided for her. The crowd had come to hear the Chairman of the Human Rights Commission and the widow of a very great man. It heard a speech that had obviously been written by the State department and ninety per cent of which was devoted to an attack against the U.S.S.R. I do not blame the Americans for talking back; but I do regret that they are using Mrs. R. as their spokesman in these polemics. She had become a symbol that stood above this quarrel around which reasonable men and women could have rallied in a final effort to find a basis not for compromise so much perhaps as for an understanding. That position has been seriously shaken by tonight's speech.

This did not seem an auspicious start. The debates and discussions continued to be tortuous but Malik, not, in Humphrey's view, a forceful chairman in Geneva, seemed to have altered his style when he chaired the Third Committee.

\section{Oct $1,[1948$, Paris $]$}

General debate on human rights in the Third Committee this morning, most of the time being consumed by our Latin-American friends. A man named Moreno ${ }^{52}$ (delegate from Colombia) began a speech at 12.55 which lasted until afternoon. Why the other delegates remained in their seats I cannot imagine. Malik in adjourning the meeting drew attention to the article in the draft declaration which says that in the exercise of your rights you must respect the rights of others. This was much appreciated by the meeting with the exception, I imagine, of the Colombian. ...

\begin{abstract}
Oct. 3 1.30 a.m. [1948, Paris] $\cdots$

The general debate on human rights continued yesterday morning and afternoon. The greatest danger that the declaration has to face at the moment, apart from Russian opposition, is the South American move to ser up a sub-committee to compare our text with the Bogota declaration. It should be said to the credit of Santa Cruz ${ }^{53}$ (Chile) that [he] pleaded with the other Latinos to abandon this idea; but $I$ am afraid his plea fell upon deaf ears.
\end{abstract}

The Pact of Bogota, known formally as the Inter-American Treaty on Pacific Settlement, was negotiated at the 9th International Conference of American States (1948). ${ }^{54}$ It included the American Declaration on the Rights and Duties of Man, which sonne delegations felt should serve as a model for the U.N. Declaration. This would have delayed the adoption, possibly indefinitely, and was no small threat since twenty of the fifty-nine delegations were from Latin America.

$$
\text { Oet 4. [1948, Paris] }
$$

The Third Committee finished its general discussion of the international declaration this afternoon, but we did not get down to an article by article study of the draft. What might be called the Bogota menace still hangs over us. Malik is doing becter as a chairman and shows much more energy and leadership than at Geneva.

After a week, the committee decided to concentrate only on the Declaration, since Mrs. Roosevelt had explained that the Commission on Human Righes would not finish its work on the covenants untill its next session. This turned out to have beer an optimistic estimate as its work on these instruments was not completed until 1954 .

Oct. 6 [1948, Paris $]$

Before adjourning this afternoon the Third Committee, after having decided to postpone consideration 
of its preamble, finally began to study article one of the draft declaration. The amendments ${ }^{55}$ to various articles are beginning to come in, and one wonders how it will be possible for the committee to deal with them all. Many of them are inspired by considerations of prestige. In other cases the authors are sincere but seem to be incapable of understanding that in a matter of this kind it is impossible for everyone to have his own way. The most sincere and best friends of the declaration keep quite [i.e. quiet] in the knowledge that in this way they can best promote its quick adoption.

One feature of this afternoon's debate was a shocking intervention by South Africa which wants to substitute "fundamental rights and freedoms" for "dignity and rights" in article one. The South African argument is that while equality may be admitted in so far as certain fundamental rights are concerned, the principle cannot be extended to all rights. 'This statement electrified the meeting and one had the feeling that everyone there, Mrs. Roosevelt and Pavlov included, was united in silent protest against it. The South African $^{56}$ however seemed unaffected by the atmosphere that he had created and did not even change his expression when the chairman pointed out that the word 'dignity' in the Charter owed its presence to General Smuts. ${ }^{57}$ Malik by the way is coing much better as chairman. For one thing he does not seem to be so preoccupied with the necessity of making friends. Instead, on several occasions, as in the one mentioned above he has not been able to resist the temptation of making a brilliant remark at the expense of a member's feelings. Whom the gods would destroy they first drive mad. ${ }^{58} \mathrm{I}$ am told that the Latin Americans are particularly annoyed. But in this case the chair has certainly been sufficiently provoked. Not only have the Latin Americans monopolized most of the debate up until now but they have created difficulty after difficulty. Unkind as the remark is it must be said that if we have an International Declaration of Human Rights it will be not because of them but in spite of them. They of course would be the first to deny this; and it can be guaranteed that their denial would be most eloquent and long winded.

Te Water's intervention forewarned the world that within two years the Population Registration Act (1950) and the Group Areas Act (1950) would make the shameful policy of apartheid a political fact of South African life.

The debate continued with agonizing slowness. One by one, each of the thirty-one ${ }^{5 y}$ articles was examined de novo and adopted over a period of two months. Some nations, like the U.S.A. and the U.S.S.R. used the forum for political purposes, while others had reservations about the universal character of certain articles. The Islamic nations demurred at the equality given the sexes and, especially, the right to change religion which, it was said, ran contrary to the teachings of the Koran. South Africa pondered, in Orwellian terms, various degrees of equality. The Latin Americans, when their hopes for incorporation of the Bogota Declaration failed, seemed intent on demonstrating the superiority of Roman Catholic to communist philosophy. Malik became ever more forceful as chairman, driving the delegates to complete their task.

Tue. Nov. 2. [1948, Paris]

Malik lost his temper in the committee this afternoon, banging the table with his gavel, and refusing the right to speak to delegates. At Geneva he was weak and tried to make friends of everybody. Here he is rigid and authoritarian, and he has succeeded in making enemies right and left. I must say, however, that I have more sympathy for him now than ever before.

$\ldots$ 
Finally, however, on December 6th, 1948 , the work was completed and the text sent to the Plenary Session of the General Assembly for adoption.

Sat. Dec 11, 1948 [Paris]

The Universal Declaration of Human Rights has now been adopted; but the miracle for which some of us had hoped did not happen. For while there were no votes cast against the Declaration, the six Slav states, ${ }^{60}$ South Africa and Saudi Arabia ${ }^{61}$ abstained. The debate in plenary was long but uninspired. I myself, who had gone to see the final act of the play, listened to very few of the speeches in full. One of the worst contributions was undoubtedly the Canadian-a niggardly acceptance of the Declaration because, it appeared from Mr. Pearson's ${ }^{62}$ speech, the Canadian government did not relish the thought of remaining in the company of those who, by abstaining in the vote, rejected it.

Humphrey's criticism of Pearson's speech is, perhaps, unduly harsh, showing the strain that Humphrey himself had been under and reflecting the shock of Canada's earlier abstention. It is true the speech was somewhat selfrighteous concerning Canada's record on the treatment of its own subjects, provided an occasion for some anti-Soviet rhetoric, and contained some carping criticism of the language employed in the Declaration, with a rather facile suggestion as to how this could have been improved. Nonetheless, it stressed the extreme importance of the U.N. human rights initiatives and noted the Declaration "would mark a milestone in humanity's upward march". 63 The Humphreys left Paris for Rome the day following this entry.

\section{TRYGVE LIE AND UN-AMERICAN ACTIVITIES}

Humphrey served under three SecretariesGeneral of the United Nations, the first of whom was Trygve Lie. ${ }^{64}$ Apart from a note warning Humphrey, on his third day of work, about loose talk to the press, ${ }^{65}$ his first major contact with Lie came two years later.

Thur. Oct. 21. [1948, Paris]

Around four o'clock Laugier left the meering to see Mr. Lie. On his return he turned to me and said: "Le père Lie veut vous voir".

= Pourquoi? =

"Pour vous parler du mauvais temps et du beau temps".

Mr. Lie did not want to talk about the weather but about the top-ranking directorship in the Social Department. It appears that both the Poles and the Indians are pressing him to fill this vacancy with candidates from their countries; and, while he did not say so, I understood that neither of these candidates were suitable. One way to solve the problem would be to promote me to the post. Hence a series of questions about my administrative experience. Could I find someone to take my place as Director of the Division of Human Rights? Etc. I told Mr. Lie that II was not looking for the post, but that I would accept it if it were offered to me. He said that he would think it over.

It is apparent that Laugier would have recommended Humphrey strongly for the position and that this would have been acceptable to Lie. There was, however, opposition to his promotion.

Wed. Nov. 3, 1948 [Paris]

Laugier called me into his office this morning to tell me that it had been decided not to appoint me as his top-ranking director. I write down the story as he told it to me and do not know whether to be annoyed or pleased. At a meeting of the A.S.G.'s this morning, Mr. Lie said that he had decided not to appoint the Pole, Litauer, ${ }^{66}$ to the post. It would be necessary to find 


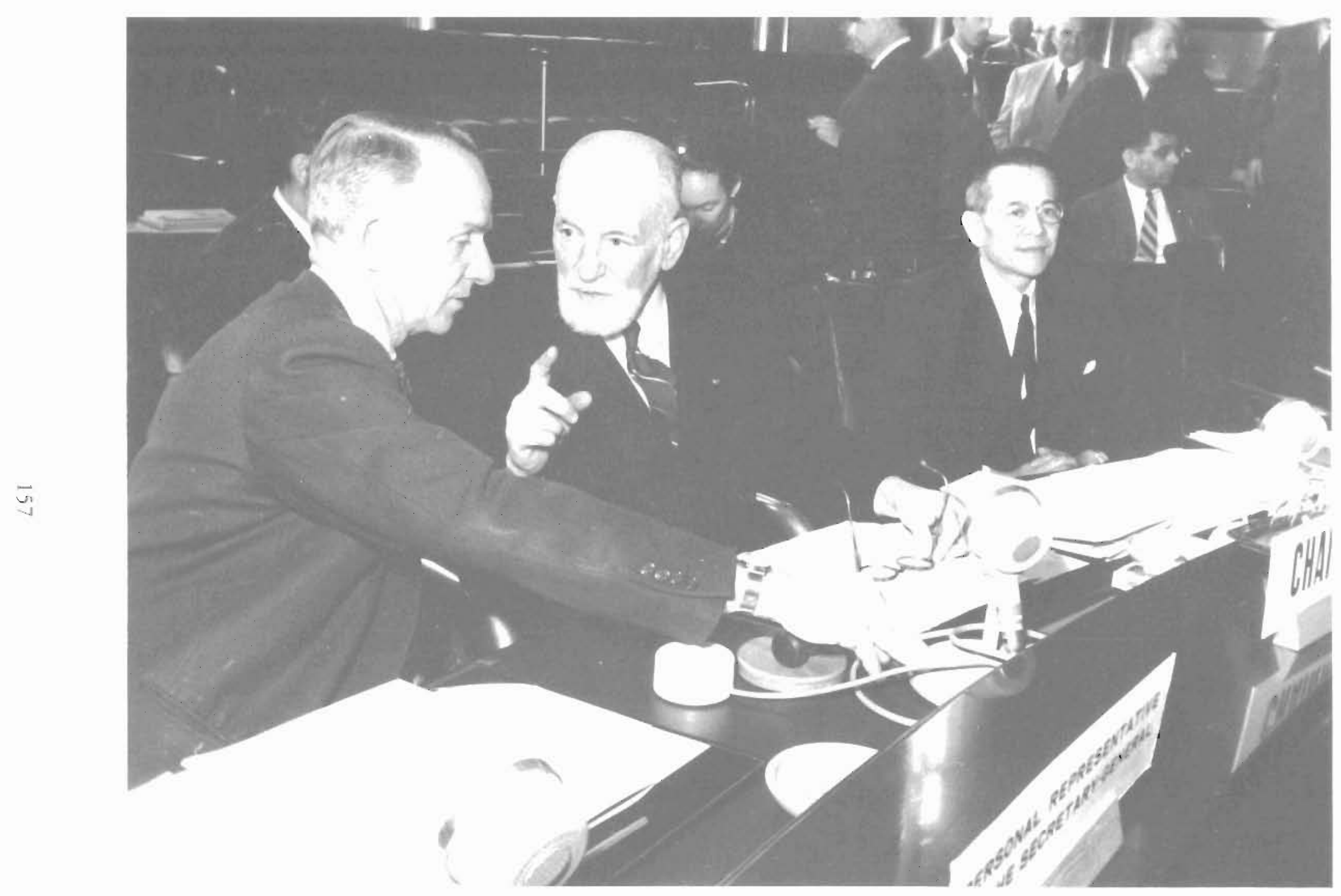

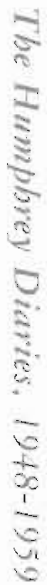

Humphrey (left) listens to René Cassin's point of view, when the latter chaired the Commission on Human Rights at Geneva in April, 1955. To Cassin's left is Mousheng Lin, a Social Affairs Officer in the U.N. Division of Human Rights. 
someone who was already in the Secretariat. How about Humphrey? At the mention of my name there was a outburst of objections. The Division of Human Rights is one of the few divisions in the Secretariat that is well run. Humphrey is one of our best directors. It would be a mistake to transfer him from important and substantive work to an administrative job. Etc. Etc. I put this down as Laugier told it to me, but I suspect that there may be more to the story than what I have heard and that the version that has come to me has been affected by Laugier's friendship for me. I must say, moreover, that the whole thing sounds both illogical and unreal. But I can also say with the utmost honesty that I have never sought nor desired the post. If it had been offered to me I would have accepted it but only because I believe that one should not refuse responsibility. Insofar as my personal life is concerned I am sure that I will be happier where I am...

One cannot tell the truth of the matter any more than Humphrey could, although he believed the objections came from Abe Feller ${ }^{67}$. Laugier may well have gilded the lily out of friendship. The suspicion remains that Lie was not a dominant man able to impose his views on others, but rather one who would seek compromise following the line of least resistance. The proof of this, for Humphrey, was to come four years later when McCarthyism arrived at the Secretariat.

The investigation concerning alleged subversive activities of American nationals working for the United Nations had begun in 1951. Humphrey hoped to have missed its worst excesses while out of the country. From October to December, 1952, the Senate Subcommittee on Internal Security began formal hearings on U.N. staff and Humphrey's hopes were dashed. The Human Rights Division was no exception to the prevailing right-wing view that the Secretariat was a base for anti-American activity. Laugier, the Division's protector and defender, had by now been replaced as Assistant SecretaryGeneral by Guillaume Georges-Picot, ${ }^{68}$ an individual Humphrey had initially characterized as "a small man in a job much too big for him".69 Yet Georges-Picot was not found wanting when the challenge came and Humphrey was to re-assess his opinion. Georges-Picot's first step was to establish a position which his Department would urge upon the Secretary-General.

Wed. 15 Oct. [1952, New York]

Georges-Picot, who continues to climb in my estimation, discussed with his directors this morning problems connected with the current investigations being carried [on] by the U.S. authorities of alleged American communists in the Secretariat. It was generally agreed that the S.G. should conduct his own investigations and that no one should be dismissed unless there were definite proof that the official had engaged in activities directed against the U.S. government. Mere membership in the communist party would not be sufficient.

Tue. 21 October. [1952, New York]

The great American witch hunt has finally reached the Division. Only last week I had been congratulating myself on our luck; for we, possibly one of the most vulnerable divisions in the Secretariat, had not been implicated in any way. But Phylis Chait, our administrative assistant, was subpoen[a]ed to appear before a Federal Grand Jury today and will appear before the Senate Investigating Committee on Thursday.

Martin Hill ${ }^{70}$ consulted me this afternoon on the whole situation. It appears that Mr. Lie is taking an important decision in the matter today. I repeated my conviction that the Secretary General should conduct his own inquiry, that the principle of guilt by association could 
not be admitted, but that any official who can be proved to have engaged in activities directed against a member state should be discharged. I do not expect that this advice will be followed. It seems that Byron Price ${ }^{7 l}$ wants to dismiss without further ado all those who refuse to answer the question whether or not they are communists!

Lie's "important decision" was that members of the Secretariat could not claim immunity when questioned on private activities or those that pre-dated U.N. employment, thus confirming Humphrey's expectation.

At this time the U.S. was in the last stages of an election campaign. Humphrey wanted Stevenson and the Democrats to win for two reasons. Firstly a Democratic loss would mean the end of Eleanor Roosevelt's involvement with the Commission on Human Rights and she was someone for whom Humphrey had great admiration and respect. Secondly he felt that a Republican victory-the party of McCarthy and others he mistrusted and feared - would lead to a deterioration of EastWest relations in general and the situation in the Secretariat in particular.

Sun. 26 Oct. [1952, New York] I have never wanted to be an American, but I would certainly like to have a citizen's right to cast a vote on 4 November. The issues are indeed so great that all of us will be affected by the outcome.

I hope that the current hate campaign against the United Nations is nothing more than an oblique attack against the State Department as some people say it is. I fear that it is much more. If an unfortunate girl has an affair with a man who subsequently murders his wife, it becomes a reason for bringing the Organization into disrepute. A popular newspaper accuses delegates and officials of abusing N.Y. traffic laws. Traditional diplomatic courtesies are distorted. And a witchhunting expedition has the U.N. as a preferred target. Obviously we are not wanted here and it would be good for our souls to breathe freer air.

Ben Carruthers has been terminated ostensibly on the recommendation of the Walters Committee ${ }^{72}$ but really because of Palthey's ${ }^{73}$ biased interpretation of that recommendation. I am very much afraid that I will not be able to do much for him because once the S.G. has taken a decision he is apt to hold to it...

Mon. 27 Oct. [1952, New York] ‥

Have just listened to Senator McCarthy's speech ${ }^{74}$ over the radio. The dishonesty of it was appalling.

To this point Lie had suspended, or dismissed in the case of temporary employees, U.S. nationals who either refused to testify or testified unsatisfactorily before the Senate Subcommittee on Internal Security. Concurrently the Walters Committee-a Special Selection Committee on Personnel Matters-was considering reorganization of the Secretariat and the reduction of staff. The Stare Department then began to hold talks with U.N. legal officials about the right of the Secretary-General to dismiss any employee without giving a reason.

$$
\begin{aligned}
& \text { Thur. } 30 \text { Oct. [1952, New York] } \\
& \text {... } \\
& \text { The situation in relation to the } \\
& \text { Secretariat becomes more difficult } \\
& \text { and more intolerable every day. It } \\
& \text { is now said that the Americans want } \\
& \text { the G.A. to give Lie the right to fire } \\
& \text { people without even stating cause. } \\
& \text { I hope that Lie will have the courage } \\
& \text { to resist all this pressure but it is } \\
& \text { unlikely that he will. Morale of the } \\
& \text { staff is at a very low level. }
\end{aligned}
$$

By the end of the year Lie was given those special powers, although an Appeals Board was established to hear the cases of permanent staff. The Secretariat continued to operate under the double strain of attack from without and management scrutiny from within. 
Nov 12. [1952, New York]

The morale of the staff is at the lowest point in the history of the Secretariat. I suspect that Byron Price has more responsibility in all this business than anyone else.

Mr. Lie has resigned and there is talk of Entezam ${ }^{75}$ as his successor.

Yes. And Stevenson has been defeated.

Humphrey clearly had a mistrust of Americans as represented by their government, especially a Republican one. This can be illustrated in another, very different, context. In 1978, the Parti Québecois had passed legislation to promote and protect the French language in Quebec, prohibiting use of other languages in certain situations. In a courageous move, Humphrey subsequently challenged Pierre-Marc Johnson, the Premier of Québec, on the philosophical basis of the law. He expressed the view that the government had made a profound mistake, since no good could ultimately come from subjugating the rights of the individual to those of the collectivity. To illustrate the distinction between the individual and the collectivity, he said that he liked and was personal friends with many Americans but as a nation they were much harder to like. ${ }^{76}$ One individual American, whom Humphrey admired, came to a tragic end:

Thur. 13 Nov. [1952, New York]

Abe Feller committed suicide roday. While nothing certain is yet known the tragedy apparently had its roots in a combination of overwork and implication in the current anti-red enquiries. His death is a tremendous loss to the Secretariat. I have always thought he had one of the best minds in the High Command to which he most certainly belonged. And on the whole I had great respect for him although I was not always in agreement with him.

Feller's suicide inevitably produced the completely unfounded accusations that he was a subversive about to be exposed. It is now accepted without reservation that the strain of his job as U.N. General Counsel and Director of the Legal Department proved too much at this juncture. He, with Lie and Price, had been largely responsible for the establishment of the Secretariat staffing policy and recruitment, including its attendant liaison with national governments. Then the unenviable task of providing legal advice to Americans, who were employed by the Secretariat and were called to testify before the Grand Jury and Senate Subcommittee hearings, had fallen to him. Their problems could, at least partially, be traced to the pollicies Feller had initiated.

Shortly afterwards Lie began to drop hints that he would be prepared to serve his full term (to 1954) if an acceptable successor could not be found.

Monday 24 November. [1952, New
York]
..
I am completely disgusted with Lie.
It now appears that notwithstand-
ing his resignation he is doing
everything to stay on. Both Oscar
Schacter 77 -with whom I had
lunch-and Georges-Picot told me
this today. I only heard the other
day about the scandalous firing of a
coloured girl-lie using his special
powers for the purpose-because
she had been going out with a
Norwegian member of the
Secretariat. This is unfortunately
not just malicious gossip.

Lie's willingness to stay on became public knowledge the following month. ${ }^{78}$

It was, therefore, a completely and uncharacteristically demoralized Humphrey who took his Christmas vacation in the Caribbean that year. He returned in January more fit for the coming fight. For Phylis Chait, accused of left wing sympathies, he could do nothing. ${ }^{79}$ Carruthers was another matter since he was considered a risk on "moral" rather than ideological grounds, which, according to the dubious wisdom of the day, might render him vulnerable to blackmail. Humphrey felt that this 


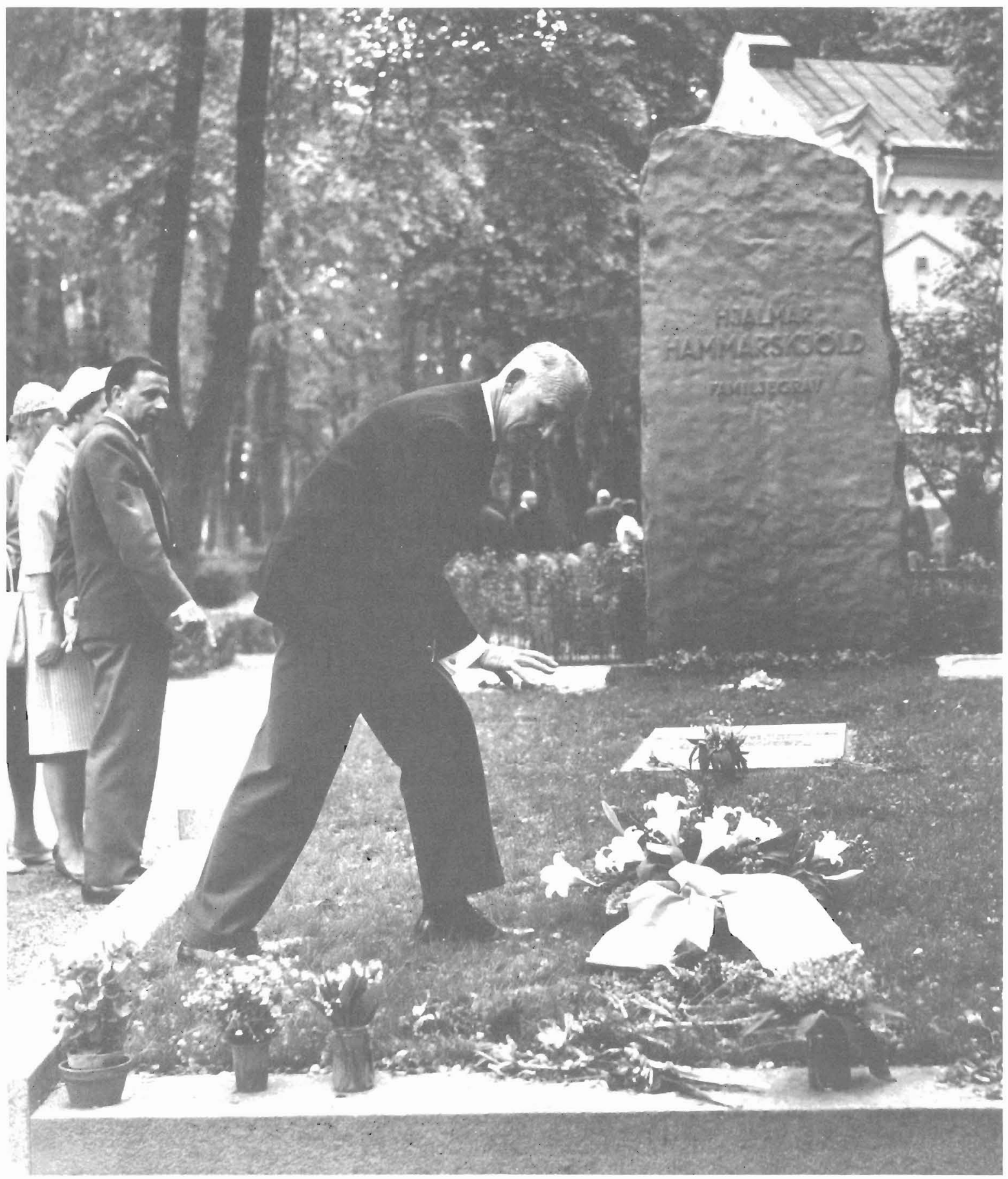

As the senior U.N. official present in Sweden on June 24th, 1962, Humphrey lays a floral tribute on Dag Hammarskjöld's tomb prior to reading a message from Acting Secretary- General U Thant. Humphrey was attending a two week U.N. seminar on judicial and other remedies against the abuse of administrative authority. 
was totally irrelevant, even if true, since Carruthers knew no secrets about which to be blackmailed nor indeed did the Division possess any such secrets. ${ }^{80}$ He appeared before the Appeals Board to contest the dismissal.

Wed. 28 Jan. [1953, New York]
Yesterday I appeared before the
Board of Appeals and testified in
the case of Carruthers. If my evi-
dence were the only thing in the
case he will certainly be reinstated.

Thur. 29 Jan. [1953, New York]

The Americans have begun to finger print their compatriots in the Secretariat; and Byron Price proudly presented himself to be the first victim. The thing that makes this crowning indignity most objectiona $[\mathrm{b}] \mathrm{l}[\mathrm{e}]$ is that it is being done with Lie's approval and cooperation by U.N. officials and on U.N. premises.

$\ldots$

Wed. 4 Feb. [1953, New York] $\ldots$

The Bureau of Personnel will apparently stoop to any depth in order to win its cases against dismissed officers who have gone before the Appeals Board. Thus, after hearing my evidence in the Carruthers case, Krac[z] kiewicz ${ }^{81}$ (apparently acting under instructions) reopened the case to say that when the S.G. decided to terminate Carruthers $^{82}$ he had in mind budgetary factors and also his opinion that the work on which C. was engaged should be done in the D.P.I. ${ }^{83}$ This, of course, is an ex post facto rationalization and, what is worse, a damned lie: for $\mathrm{K}$. was in my office only the other day discussing candidates for the Carruthers post.

The witch hunt continued sporadically for the rest of the year, mostly concerning successful appeals, but the investigation turned to the scrutiny of other areas. The Grand Jury, despite its presentment that there was "infiltration into the United Nations of an overwhelmingly large group of disloyal United States Citizens," did not bring a single indictment against any individual-although many careers were ruined-as a result of its hearings concerning U.N. personnel. ${ }^{84}$

In defense of his role in the crisis, Lie stated his view that the eighteen U.N. permanent staff members, who had pleaded the Fifth Amendment, "had gravely and irresponsibly transgressed the Staff Regulations", "that they had not conducted themselves as international civil servants should", and that they tended "to discredit the Secretariat as a. whole, to cast suspicion on all the staff and, still more serious, it imperilled the position of the Organization in the host country". He concluded that, once he had secured the authority, he had no option but to terminate the employees to preserve the position of the United Nations. He did, however, give the nine permanent employees the chance to reconsider and testify, but all refused the opportunity. He had already terminated all temporary employees in a similar situation, where no reason needed to be given and the case could not be appealed. He felt that letting people go quietly was a better way to handle this type of situation than the American Congressional approach, with all its attendant publicity. 85

Scholars, who have examined the question since, tend to come to conclusions more in keeping with Humphrey's view. Evan Luard notes that the employees had a perfect constitutional right to refuse to answer and that that refusal "in itself proved nothing about the suitability of such people to hold posts within the UN Secretariat: the Amendment would of course have no meaning at all if a refusal to answer was taken as a confession of guilt". ${ }^{86}$ He continues:

Lie subsequently endorsed this view [of a carefully selected committee of jurists to advise him], saying that staff members had a "positive obligation to refrain from conduct which would draw upon themselves grave suspicion of being a danger to the security of a particular 
state". 87 This was an extraordinary conclusion to draw on the basis of a single refusal, under an ancient constitutional safeguard, to answer questions, unaccompanied by the smallest evidence of subversive activity or other breach of duty. ${ }^{88}$

James Barros, in a recent monograph examining Lie's role as Secretary-General, is more charitable. He summarized the events as follows:

\begin{abstract}
A resolute and less pliant secretarygeneral might have handled the situation better, but it is doubtful that anyone could have long resisted the enormous pressure felt both from Congress and the American public.... Lie had not decked himself with glory, but the Truman administration, by not vetting Americans being recruited for the secretariat, had failed to give Lie the initial assistance he had requested. Compounded by demagoguery and the impact of the Korean war on American public opinion, events overtook both Lie and the Truman administration. On this matter, wisdom had been in short supply everywhere. ${ }^{8 \%}$
\end{abstract}

Barros concluded, however, that Lie's handling of the crisis was weak, his attempts to stay on pathetic, and his vilification of his successor sordid. $\%$ For an acceptable replacement was found for Lie, and Dag Hammarskjöld took office in April, 1953.

\section{HAMMARSKJÖLD AND THE AERODYNAMICS OF HUMAN RIGHTS}

Humphrey found in the new SecretaryGeneral a man of quite different mettle, although he did not start working closely with him until I954.
Friday 29 Jan. [1954, New York]
...
Much more important of course is the education of Hammarskjold himself. He continues to be an enigma for me. That he is keenly

intelligent there can be no doubt. I also find myself in agreement with him on specific issues. But I wonder about the direction in which he is going. I sometimes think that his purpose is to reduce the nonpolitical activities of the organization to a minimum.

Humphrey was not to be kept long in suspense. Hammarskjöld had inherited Lie's re-organization plan and had already begun to cut back on staff. Humphrey, in addition to his regular duties, had been acting principal director of the Social Department since August, 1953. He was, therefore, involved with making proposals about the organization of all Divisions within the Department.

$$
\text { Sun., } 7 \text { Feb. 1954. [New York] }
$$

I worked most of yesterday getting together my ideas for the suggestions that the Department will have to put forward to the S.G. for review of the human rights programme and reorganisation of the Division. According to Katzin" the S.G. has never expressed himself so clearly on the question in my presence-the S.G. wants to relieve the Secretariat from some of its duties so that it can play a more important role in fixing policy. This sounds like rationalisation...

Sat. 13 March [1954, New York]

My experience of the last weeks would fill a chapter in a future history of the U.N. Secretariat. And that chapter, I am afraid, may prove to be a tragic one; for it looks more and more as if the S.G. intends to deliver a body blow.

On Tuesday he called me to his office "to acquaint me with his thinking" about the reorganisation of the Social Department. This thinking is not supposed to crystal[1]ize until Georges-Picot retires; but it is obvious that the S.G. had already established the broad lines of reorganisation in his mind even before he began his review. 


\section{The Humphrey Diaries, 1948-1959}

The activities which will suffer most in the Social Department are population and human rights...

I warned him that as far as human rights at least are concerned he is making a great mistake. The work load should in fact increase as soon as the Commission finishes with the draft covenants. The S.G. therefore will merely expose himself to attack without being at all sure that he can achieve his objective. But I might just as well have saved my breath. He is very sure of himself and his mind is made up.

Two things that he said to me are worth putting down for the record. He would like to throw the Human Rights Covenants out of the window. I checked him up on this and suggested that a better policy would be to put them on ice until there is an improvement in the political climate. Later when boasting about what he called the successful elimination of the Department of Financial and Administrative Services, he said that he found that he could do himself everything that the A.S.G. ${ }^{22}$ had done in the past. This kind of activity, he said, was more useful than seeing delegations "which was a waste of time". That remark, I think, gives the true measure of the man. In spite of his brilliant mind and his possible (but yet unproved) administrative ability he lacks the qualities of statesmanship.

Thus Humphrey found that he and Hammarskjold held radically opposing views on the best way to achieve peace and the place of the human rights programme in achieving this goal. Humphrey, the lawyer, felt the covenants were a vital component, giving teeth to the principles of the Declaration, which were not binding on any nation but were beginning to have the force of customary law. Apart from his desire to make economies through reorganization, Hammarskjöld felt that peace could best be assured through the Secretary-General engaging in high level shuttle diplomacy. Worse, he felt that the debates concerning the covenants actually increased tensions between nations. He considered that human rights should not be a function of the U.N. but rather be under the auspices of some other international body, such as UNESCO. The situation deteriorated when GeorgesPicot, not an admirer of Hammarskjöld, returned from his leave of absence. 'The diaries over the next few months tell an enthralling, though lengthy, tale of the struggle between the Secretary-General and those who would retain a significant role for the Human Rights Division, as well as the intrigues that went on in many areas as a result of the reorganization plan. The end result could be considered a draw. Hammarskjöld was able to cut back on the staff and influence of the Division, but it was not eliminated, reduced to section status, or placed under the auspices of another body.

1955 began with a replacement for GeorgesPicot as Assistant Secretary-General and the end of Humphrey's position as acting principal director in the Social Department. Georges-Picot's successor, the economist Philippe de Seynes, ${ }^{93}$ was less sympathetic to the human rights movement than Laugier and less adverse to the Secretary-General's policies than Georges-Picot. Humphrey continued to contemplate a return to acalemic life.

Thur 19 May [1955, New York] ... today I came to a decision which I think will stick. I will. stay in the U.N. for $2 \frac{1}{2}$ years until the end of Hammarskjold's term. If he is reappointed I will immediacely resign. If he does not stay I will wait and see.

On June 15th, Humphrey had a long discussion with Hammarskjöld on the human rights programme. Hammarskjold stated that his attitude towards the programme was determined by his concern for bigger issues. He wanted Humphrey to keep the programme going at the slowest pace possible, saying: "There is a flying speed below which an airplane will not remain in the air. I want you to keep the program at that speed and no greater". "For Hamnarskjold it came down to a question of aerodynamics - the efficiency and efficacy of the airplane of shuttle diplomacy 
versus the pragmatic but ponderous flight of the covenants and other international instruments.

Thus began a long and uneasy phase in the history of the Human Rights Division. Humphrey saw his role as attempting to keep the programme going, at whatever speed, in the face of supervisory opposition. Eventually Humphrey brought things to a head:

\begin{abstract}
New York. 23 Aug. [1955]
I asked Hammarskjold today to find me another job where I could make a significant contribution. I said that $I$ was not the kind of man that he needed to implement his present human rights policy, that I had come to the U.N. to do an important job, that I had done it well whatever he might think of the programme, and that I was not willing to share the fate of certain officials who had become prisoners of insignificant jobs and who continued to draw salaries while doing litthe more than routine work, if that. He seemed surprised at first and then said that he needed my "idealism" in the job. But after I insisted I was very serious he said that the next move was his. I did not go there to argue with him about his policies and resisted the temptation to answer some of his comments. His manner was frank and friendly and in spite of my disagreement with him on so many fundamentals I could not help liking him. I compare him very favourably to Georges-Picot and, of course, de Seynes.

I do not really expect anything to come of this démarche; but I feel better after having made it. I am never comfortable when sailing under false colours; and now Hammarskjold knows exactly where I stand.
\end{abstract}

After this the relationship between Hammarskjöld and Humphrey appeared to ease. Hammarskjöld's "move" was long in coming. Two years later the Human Rights
Division was moved out of the Department of Economic and Social Affairs and placed under Sir Humphrey Trevelyan. ${ }^{95}$ However, Humphrey felt that Hammarskjold began to be less visibly opposed to the human rights programme at this juncture. ${ }^{\%}$ when Humphrey's deadline of two and a half years had passed, his thinking had altered:

Fri. 27, 1957. [September, New York]

Yesterday the Secretary General was unanimously re-elected for another term. It would certainly be wrong to say that he has become an enthusiastic supporter of the human rights programme; but there is very real evidence of an evolution in the right direction. For example, this summer he personally corrected a paragraph which Lin Mousheng ${ }^{\text {? }}$ had prepared for the Introduction to the Annual Report; and by emphasizing the positive aspects of the programme showed his understanding of and sympathy with the new direction into which we are trying to steer it.

By the time Hammarskjöld was tragically killed in an air crash over Rhodesia, he had certainly gained a greater respect for the work of the Division and Humphrey had come to appreciate more the Secretary-General's diplomatic initiatives in the Congo crisis. If a lasting peace is one day achieved, only hindsight will tell us whether the words of the instruments or the tongues of the diplomats were the more efficacious in that achievement.

\section{HOME THOUGHTS FROM ABROAD}

Throughout his career at the U.N. Humphrey's thoughts often turned to McGill and the quieter world he had left behind. At first these were a source of comfort and enjoyment, when he took time out from his hectic schedule to socialize with former colleagues and students. These meetings always struck a positive note.

\section{Oct 4. [1948, Paris]}

Two of my old students from Law Faculty days, Choquette ${ }^{98}$ and 
Noble, ") turned up at the Palais this morning. Took them out to lunch and had a long talk about McGill that refreshed me no end.

Monday, Oct. 18 [1948, Paris]

Had lunch with Ross Clarkson, ${ }^{100}$ one of my old students at the Law Faculty. He won the gold medal at the final examinations last Spring. One of the best students I ever had.

Fri. Nov. 26 [1948, Paris]

Had two of my old students at the Law Faculty to dinner tonight: Bill Noble and Joan Gilchrist ${ }^{101}-$ also an ex-Université de Montréal man called Forticr. ${ }^{102}$ I enjoyed the evening immensely.

A return to academic life had a very positive appeal even at an early stage when the U.N. work was exciting and interesting. When there was a possibility of a promorion he noted: "I am sure that I will be happier where I am-and I would be still happier were I back at McGill". "103 Later, during the demoralizing Un-American activity investigations and the cutbacks imposed by Hammarskjöld, Humphrey began to investigate actively the possibility of returning to McGill.

Montreal, Mon. 31 March. [1952]

We came up here last night on the "D\& H"IO) after having dined with Claude 105 and Gerard. Magnificent view from the Division's offices before taking the train.

Had lunch with Cyril James ${ }^{106}$ at the Rit $z$. There will be no difficulty about coming back to McGill. ...

Montreal, Tue., 1 April [1952] ...

I then called on Dean Meredith. ${ }^{107} \mathrm{He}$ was pleasant but did not commit himself. I feel however that there will be no difficulty about coming back to McGill if I still want to in the Fall of 1953.
Strangely enough my desire to come back is not nearly so strong. I have no intelligent reasons for this change in atritude. 'Today's inclination is to wait and see.

..

Wed. 2 April [1952, Montreal]

It must be admitted, however, that most of the talk $10 \mathrm{~s}$ was about me-my job, the U.N., my thoughts about returning to McGill. A propos of this latter, I had a talk with Dean Meredith in the morning. It was satisfactory but non-committal.

Humphrey did not return to McGill in the Fall of 1953, although whether through his or Meredith's ambivalency is hard to say. The diary breaks off for a period of four months. The tale is taken up again in mid-August in Sandy Cove, Nova Scotia, but in a different vein. Thirty-seven different species of birds were seen, identified and described in almost ferocious detail, along with other commentary on the natural surroundings, but, for two weeks, no word of explanation. After the vacation Humphrey returned to New York.

60 Sutton Place South 18 Sept. (Thursday) [1952, New York]

When Jeanne asked me tonight why I didn't write in my journal anymore I replied that I had had enough of $i t$ and that $I$ even intended to destroy it. And I may do precisely that. It contains too many snap judgements-some of them certainly unjust-about too many people.

Humphrey's criticism of the judgemental nature of the diaries is certainly valid, but that is also their value. His opinions, retrospectively formed and well considered, can be found in his books and other writings. Yet these memoirs would be tempered by hindsight, and reflect, for example, his evolving political orientation, literary tastes and religious convictions. It is also important to know how he, as with any recorder of events, felt at the time, regardless of how well- or ill- 
conceived those feelings were. This knowledge can explain motivations and actions far more readily than reflections developed in tranquillity. It seems evident that posterity owes a debt to Jeanne Humphrey, herself a diarist, not only for allowing Humphrey sufficient time to make the entries, but also for the fact that he began writing again and did not destroy the diaries. "ily Away from Montreal he still thought fondly of McGill:

Thur. 30 Oct [1952, New York] Yesterday at 6 Frank Scott, King Grordon and $I$ had drinks together at the U.N. bar. It was a gay hour and took me right back to McGill.

In the Human Rights Division things remained dark in the early years of the Hammarskjold regime. In retrospect, Humphrey does not consider the work he did on drafting the Declaration, or helping to get it and the covenants adopted, as his most significant contribution to the field of international human rights. These things were merely his job. He believes that keeping the Division going and the programme active in the face of very great difficulties to be the most important achievement of his public career. ${ }^{110}$ It is, perhaps, for this reason that he stayed on despite a continuing search for a suitable academic post at McGill or elsewhere, and the offer of other positions abroad. He remained at the U.N. until 1966, his compulsory retirement date, when he returned to McGill for the last time. Humphrey still teaches at his beloved Faculty of Law. In 1988, he was awarded the quinquennial U.N. Human Rights Award and still travels and lectures extensively at home and abroad.

\section{ENVOI}

The Humphrey diaries are a rich source for the study of the human rights activity of the U.N., regardless of the amount of caution required in their use. To date only Humphrey himself has used them in the preparation of the autobiographical account of his career, but they will soon be made available to other scholars. Part of their value lies in the fluency of language used and their great legibility. The reader can follow thoughts and emotions clearly, without the requirement of interpret- ing staccato notes or obscure references. Humphrey wrote the diaries for himself, however, and not for posterity:

Sun. Nov. 14. [1948, Paris] ...

Here ends the first book of this journal. When I began it three and a half months ago I hardly expected to persevere this long. But the fact is that I enjoy writing it and, if I live that long, I will enjoy still more reading it in twenty years.

One hopes that Humphrey still feels the same after forty years, as we read along with him. 


\section{Notes}

1. Horace's dictum about the writing of epics, based on Homer's Odyssey, is that they should begin in the midst of things. Ars Poetica 148.

2. John P. Humphrey, Human Rights and the United Nations: a Great Adventure (Dobbs Ferry, N.Y.: Transnational Publishers, 1984), 1. Henri Laugier (1888-1973), after a distinguished pre-war academic career, went to the University of Algiers as Rector in the fall of 1943 and returned to France in 1944 after the liberation. He was U.N. Assistant SecretaryGeneral from 1946-1951.

3. Alan John Hobbins, "René Cassin and the Daughter of Time: the First Draft of the Universal Declaration of Human Rights," Fontanus 2 (1989), 7-26.

4. It had previously been called the International Bill of Human Rights, and was to include covenants and means of implementation. As things turned out, only the Declaration was completed in 1948 and it was not until 1966 that the covenants were opened for signature.

5. Canada was not ostensibly opposed to any of the rights enumerated, but caught up in its peculiar national dilemma as to whether certain clauses dealt with rights that were under provincial rather than federal jurisdiction. The federal delegation stated that it did not feel it could vote for clauses where the jurisdiction was unclear or was certainly provincial. The president, John T. Hackett (1884-1986) of the Canadian Bar Association was, however, as opposed to U.N. human rights programme as his American counterpart [see infra note 17] and so the Canadian abstention may have refleted more than simply this jurisdictional concern. Humphrey, 79 .

6. Humphrey used a variety of ways to express dates and these are given in this article as they appear. Although the year and place are usually clear from the context, these have been added in brackets [] for convenience in all places where omitted.

7. André Gide (1869-1951), Journal, 1939-1942. Paris: Gallimard, 1946.
8. Simone de Beauvoir (1908-1986), Tous les bommes sont mortels. Paris: Gallimard, 1946. Humphrey began reading this book, with its immortal protagonist, Fosca, on August 11th. By August 25th, he had pronounced it as a "poor book", an opinion shared by many contemporary critics.

9. Jeanne Marie Louise Godreau, who came from the lower St. Lawrence river in Quebec.

10. September 3rd, 1929.

11. Emmanuel Suhard (1871-19/19) became a Cardinal in 1935 and was Archbishop of Paris from 1940) until his death.

12. Frank Scott (1899-1985) was a Canadian poet and constitutional lawyer. He was on the McGill Faculty of Law from 1928, serving as Dean (1961-1964).

13. (John) King Gordon (b. 1900) was a United Church minister and educator. He later served the United Nations in a number of capacities including work at the Division of Human Rights. His father, the Reverend Charles William Gordon (1860-1937), was better known by the pseudonym Ralph Connor, the author of many adventure books.

14. David Lewis (1909-1981) was an M.P. and national leader of the New Democratic Party, successor to the C.C.F.

15. Frank Underhill (1889-1971) was a noted historian and educator.

16. Eugene Forsey (1904-1991) was a Senator and former Director of Research of the Canadian Labour Congress and its precursor, 1942-1966.

17. Frank E. Holman (1886-1967) was an influential Seattle lawyer who, in addition to being President of the American Bar Association, had been on the American Bar Committee for Peace and Law through the United Nations (1946-47).

18. Louis Dolivet of France was international editor of United Nations World, a shortlived commercial journal not connected to the U.N.

19. American Academy of Political and Social Science. Amals, vol. 255 (1948), 21. 
20. Barry Goldwater. Why not Victory? (New York: McGraw-Hill, 1962), 102.

21. Jean Cocteau (1889-1963), Thomas limpostezr. Paris: Gallimard, 1948. Originally published in 1923.

22. Charles Malik (1906-1987) of the Lebanon was an enormously influential figure in United Nations human rights activity. He was Rapporteur of the Commission on Human Rights and became Chairman after Eleanor Roosevelt.

23. A.P. Pavlov, nephew of the famous physiologist and apparently mediocre inheritor of a great name, was becoming the principal Russian spokesperson on humanitarian issues, serving on the Commission on Human Rights, the ECOSOC Committee and the Third Commitree of the General Assembly.

24. Humphrey had studied political science as an undergraduate under the celebrated Canadian humourist, Stephen Leacock (1869-1944). In Nonsense Novels (1911) Leacock wrote: "Lord Ronald said nothing: he flung himself from the room, flung himself upon his horse and role madly off in all directions". According to Colombo's Canadian Quotations (Edmonton: Hurtig, 1974), 337, Theodore Roosevelt used the sentence in a speech and it is one of the few internationnally known quotations of Canadian origin.

25. Marie-Hélène LeFaucheux (1904-1964) was the French delegate and Chairman of the Commission on the Status of Women. She was a member of the wartime resistance and wife of Pierre-André Lefaucheux, President of the Renault Automobile Works.

26. These three conventions, only one of which finally came into force, were forwarded from the Geneva Conference on Freedom of Information (1948).

\section{Malik}

28. Walter Maria Kotschnig (1901-1985), an Austrian-born naturalized American writer and diplomat, was then a deputy representative on the U.S. delegation to ECOSOC.

29. George Forrester Davidson (1909- ) was Deputy Minister in the Department of
National Health and Welfare and a member of the Canadian delegation to ECOSOC. He became President of ECOSOC in 1958.

30. P.C. Chang (1892-1957) of China was Vice-Chairman of the Commission on Human Rights and, according to Malik, never failed to broaden the perspectives of the drafters by frequent reference to the wisdom and philosophy of the Orient. Hobbins, 10.

31. Julius Kate-Suchy (1912-1971) was the Polish ambassador to the U.N. He defected to) Denmark in 1970.

32. The Third Committee of the General Assembly dealt with social, cultural and humanitarian matters.

33. Humphrey represented the U.N. at the International Law Association Conference.

34. The Humphreys arrived in Concarneau on September 3rd, 1948, their ninctcenth wedding anniversary.

35. Hotel de Cornouailles.

36. Gabrielle Roy (1909-1983), Ma chère petite seur; Lettres a Bermadette, 1943-1970) (Montréal: Boréal, 1988), 243.

37. Jacques Prévert (1900-1977) Paroles. Paris: Éditions du Point du Jour, 1947. Prévert was then a poet and short-story writer, who later became famous as a screenwriter. Paroles was a recent collection of his poems.

38. Roy, 243.

39. Peter Aylen (1910-1990) was a career U.N. official and, at the time, Director of the Radio Division in the Department of Public Information.

40. The First Committee of the General Assembly dealt with such political issues as disarmament and security.

41. Palais de Chaillot, where the General Assembly was in session.

42. When Laugier arrived in Washington early in the war, speaking no English, a position was found for him on the recommendation of the Rockefeller Institute as a professor of physiology at the Université de Montréal. 
He had been a titular professor in this field at the University of Paris.

43. In this context "That man" clearly refers to mankind and not to Lecomté du Noüy. The controversial Lecomté du Noüy had, in fact, died over a year previously in New York City. His book was originally published in English and the French edition came out posthumously in 1948.

44. Mary Lecomté du Noüy, The Road to Human Destiny (New York: Longmans, 1955), $238 \mathrm{ff}$.

45. Bodil Begtrup (1903-1987) was the first chairman of the Commission of the Status of Women and President of the Danish Council of Women. Later she was Danish ambassador to Switzerland (1956-1959) and Portugal (1968-1973).

46. Emile Saint-Lot (b. 1904) had been Dean of Law at Port-au-Prince and was a Haitian representative to the U.N.

47. James Thorn (1882-1956) was New Zealand delegate to ECOSOC and later chairman of the Council (1949).

48. Professor (later Senator) Fernand Dehousse (b. 1906) was the Belgian representative on the Human Rights Commission.

49. Humphrey's relationship with Begtrup as chairman of the Commission on the Status of Women had convinced him she would not be a good chairman in the upcoming debate, should Malik become indisposed and despite his soon-to-be-revised opinions on Malik. The alternative interpretation-that Begtrup's vicechairmanship would make Malik ill- can be discounted.

50. Paul Ramandier (1888-1961) was a socialist French politician with ministerial appointments in both the Third and Fourth French Republics. He had been the first Prime Minister of the Fourth Republic (1947) and was, at this time, Minister of Defense.

51. Jean Sarrailh (1891-1964) was Rector of the University of Paris from 1947-1961, and later President of the French Commission to UNESCO.
52. Ramirez Moreno. The summary records of the 90th meeting indicate luncheon adjournment was at $1.30 \mathrm{p} . \mathrm{m}$.

53. Herman Santa Cruz (1906- ) was Chile's permanent representative to the United Nations and delegate to, later Chairman (1950) of, ECOSOC.

54. This conference also produced the basic constitution of the Organization of American States.

55. The Third Committee had to deal with one hundred and sixty-eight resolutions containing amendments.

56. Charles Theodore te Water (1887-1964), formerly President of the Assembly of the League of Nations (1933), was South African Ambassador at large (1948-49).

57. Jan Christian Smuts (1870-1950) was Premier of his country when he attended the San Francisco Conference in 1946, which created the United Nations, but had been defeated in the election of 1948. Usually known by his First World War British rank of general, he had been made a field-marshal in 1941 .

58. This represents a faily common maxim dating from the fifth century B.C., the version Humphrey cites being found in Longfellow's The Masque of Pandora pt. vi, line 158. Boswell Life of Jobnson (Oxford, Clarendon, 1971, vol. IV, 181) described it as a phrase everybody repeats, but nobody knows where to find. It is now generally attributed to Euripides, although Plutarch ( $Q$ uomodo Adoloscens Poemata Audire Debeat 106) states it is an adage of Aeschylus and others suggest Sophocles' Antigone as the source.

59. Owing to a British amendment in the Plenary, combining the second and third articles, the final Declaration had only thirty articles.

60. The Soviet Union, Ukraine, Czechoslovakia, Yugoslavia, Poland, and the Byelorussian S.S.R.

61. Saudi Arabia still believed that the provisions regarding the right to change religion ran contrary to the Koran. The fact that other 
Islamic nations did not follow the Saudi lead can be credited to the defence of the Declaration offered in plenary by Sir Muhammad Zafrulla Khan (1893-1985), Pakistan Minister of Foreing Affairs and leader of its delegation to the U.N.

62. Lester B. "Mike" Pearson (1897-1972) was then Chairman of the Canadian delegation and Secretary of State for External Affairs. He was awarded the Nobel Peace Prize in 1957 and, later, became Prime Minister of Canada.

63. U.N. Document A/PV 18210 December 1948.

64. Tryvge Lie (1896-1968) was a lawyer and politician, who had been Foreign Minister of the Norwegian government-in-exile during the war.

65. Part of an article in the New York Times (2 August 1946. p. 4.), which followed a quote from Humphrey, led some readers to believe he was responsible for the remaining unflattering sentiments about Assistant Secretary-General Arkady Sobolev (1903-1964).

66. Dr. Stefan Litauer (1892-1959) was an academic, journalist and diplomat, and at that time Minister-Counsellor and Chargé d'Affaires in Washington. He was "unsuitable" for the post because the State Department concluded his appointment would be detrimental to national security, and so put pressure on Lie to reject him. James Barros, Trygue Lie and the Cold War (Dekalb, III.: Northern Illinois University Press, 1989), 313.

67. Humphrey, 3. Abraham Feller (1904-1952) was U.N. General Counsel and Director of the Legal Department from 1946-1952.

68. Guillaume Georges-Picot (b. 1898) of France was Assistant Secretary-General for Social Affairs from 1951-1954.

69. Diaries, 27 March 1952.

70. Martin Hill (1905-1976) was an Irish born British diplomat who had worked in the Secretariat of the League of Nations. His imposing title at the time was Deputy Executive Assistant to the Secretary-General and Director of Co-ordination for Specialized Agencies and Economic and Social Matters.

71. Byron Price (1891-1981) of the U.S.A. was Assistant Secretary-General for Administration and Financial Services. He and $A$ be Feller [see infra] were the only U.S. nationals out of some three thousand to be cleared by the State Department prior to being hired by the U.N.

72. Named for its British chairman, Francis Walters (1888-1976), former Deputy Secretary-General of the League of Nations.

73. Georges Palthey (1910- ) of France was Director of Personnel (1948-1954) and Deputy Director, later Deputy Director-General, of the U.N. Office at Geneva (1954-1973).

74. A $\$ 50.00$-a-plate "McCarthy Broadcast Dinner" at the Palmer House, Chicago.

75. Nasrollah Entezam (1900-1983?) was Iranian Ambassador to the U.S. and his country's representative to the U.N.

76. Pierre-Marc Johnson told this story on November 28,1988 , at a cocktail party held in his honour when he joined the McGill Faculty of Law. He added that, while he did not concede Humphrey's point, he looked forward to renewing the debate.

77. Oscar Schacter was Director of the General Legal Division of the Legal Department.

78. New York Times 4 December 1952, 2.

79. Chait was subsequently "exonerated" and spent her whole career in the Secretariat.

80. Lie himself was mystified by the American notion that the U.N. was bristling with secrets. He noted: "There was nothing to spy on in the United Nations. Governments did not give it secret information they wished to withhold. Its meetings and documentation were pulic property". Trygve Lie, In the Cause of Peace: Seven Years with the United Nations (New York: Macmillan, 1954), 388.

81. Karol Kraczkiewicz, a Personnel Officer, who became Chief of Departmental and Staff Services, Office of Personnel, in 1954 . 
82. Ben Carruthers (1911-) left the U.N. in 1954, going on to an extremely successful career as a travel writer.

83. U.N. Department of Public Information.

84. Andrew Cordier and Wilder Foote, Public Papers of the Secretaries-Ceneral of the United Nations. Vol. I, 1946-1953 (New York: Columbia University Press, 1969), 498.

85. Lie, Chapter XXI "The Communist Issue in the Secretariat," 386-405.

86. Evan Luard, A History of the United Nations (New York: St. Martin's Press, 1982), vol. I., 354-5.

87. Lie, 396-7.

88. Luard, 355

89. Barros, 320

90. Ibid, 320-341. Lie made a concerted effort to stay on despite the opposition of all major powers and the Secretariat staff. He even stooped, when all else failed, to circulating rumours that Hammarskjold was homosexual.

91. Colonel Alfred G. Katzin of South Africa was Director of the Bureau of Personnel from April to December, 1954.

92. Byron Price recommended that his position and department be abolished upon his retirement. Hammarskjold was not slow to move on this suggestion.

93. Philippe de Seynes (1910- ) of France was Under-Secretary (1955-1968) and Assistant Secretary-General for Economic and Social Affairs (1968-1974).

94. Humphrey, 205. Although the diary covers this meeting in detail, this quote is only found in Humphrey's book.

95. Sir Humphrey Trevelyan (1905-1985) was Under-Secretary for Special Political Affairs in 1958.

96. Humphrey, 208.

97. Mousheng Lin (b. 1906) had been recruited for the Human Rights Division by Humphrey, on P.C. Chang's recommenda- tion, in 1949. He was the author of Men and Ideas: an Informal History of Chinese Political Thought.

98. Jerome Choquette (1928- ) had graduated from the McGill Faculty of Law in 1948 and was attending the University of Paris. He is a former Quebec Minister of Justice (1970-1975) and Education (1975) and is currently the Mayor of Outrement, Quebec (1983-).

99. William R. Noble (1923- ) took his BCL (1948) after war service with the Canadian Navy. He attended but did not complete courses at the University of Paris in 1948-49. Semi-retired, he still practices law in Montreal.

I00. Ross T. Clarkson, QC (1922-) received his BCL (1948) and won the Elizabeth Torrence Gold Medal in Civil Law. He took a doctorate at the University of Paris. He is currently senior partner in the Montreal firm of McCarthy, Tetrault.

101. Joan C. Gilchrist (1915- ) was a lieutenant in the Canadian Navy during the war and started at McGill (BCL, 1948) immediately afterwards. She took her doctorate in Paris and practised law in Montreal until she joined the family business. She retired to Victoria, B.C., in 1981 .

102. D'lberville Fortier (1926- ) had graduated with an LL.B. from the Université de Montréal in 1948, and was studying in Paris. He was Canada's Official Languages Commissioner, 1984-1991.

103. Diaries, 3 November 1948.

104. Delaware and Hudson railway.

105. Claude Godreau, Humphrey's brotherin-law, and his friend, Gerard Pigeon.

106. Frank Cyril James (1903-1973) was Principal of McGill University from 1940-1962.

107. William Meridith (1904-1960) was Dean of Law from 1950-60.

108. With his sister, Ruth who arrived that day from Vancouver. 
109. Jeanne Humphrey's influence can often be detected at points where writing the diary had become a chore and Humphrey contemplated abandoning it. For example the entry for June 15th, 1957, tells us: "Jeanne says that I should keep up this diary. The difficulty is that $I$ am usually too tired in the evenings and think only of relaxation".

110. Humphrey, "The Dean who never was," First Annual Humphrey Human Rights Lecture, McGill Faculty of Law, 1989. 